DOI: https://doi.org/10.24127/ajpm.v9i4.3150

\title{
INSTRUMEN EVALUASI KEMAMPUAN PENALARAN ADAPTIF MATEMATIS MAHASISWA
}

\author{
Rina Oktaviyanthi ${ }^{1 *}$, Ria Noviana Agus ${ }^{2}$ \\ $1^{*, 2}$ Pendidikan Matematika, Universitas Serang Raya, Serang, Indonesia \\ *Corresponding author. Universitas Serang Raya Jl. Raya Serang - Cilegon Km.5, 42162, Serang, Indonesia \\ E-mail: $\quad$ rinaokta@unsera.ac.id $^{1 *}$ \\ riaagus@unsera.ac.id ${ }^{2)}$
}

Received 10 October 2020; Received in revised form 13 December 2020; Accepted 27 December 2020

\begin{abstract}
Abstrak
Meningkatkan kemampuan penalaran adaptif matematis mahasiswa tingkat pertama universitas merupakan suatu tantangan nyata terutama pada mata kuliah dengan tingkat abstraksi tinggi. Agar proses peningkatan kemampuan tersebut dapat dilakukan secara optimal perlu didukung oleh instrumen evaluasi yang kompatibel. Namun instrumen evaluasi yang dinyatakan layak digunakan belum tersedia, khususnya di lingkungan Pendidikan Matematika, Universitas Serang Raya. Instrumen evaluasi dinyatakan layak digunakan jika memenuhi kriteria valid dan reliabel pada proses pengembangannya. Berdasarkan hal tersebut, maka tujuan penelitian ini adalah mengembangkan instrumen evaluasi kemampuan penalaran adaptif matematis mahasiswa. Pendekatan penelitian menggunakan deskriptif dengan metode content analysis dan expert review pada validitas instrumen melalui tahapan instructional phases design yakni analysis and design, development dan evaluation. Secara umum hasil uji keseragaman dan keterbacaan validator menunjukkan nilai Asymp. Sig. > 0,05 yang memiliki pengertian bahwa validator memberi pertimbangan seragam pada validitas muka dan isi instrumen evaluasi kemampuan penalaran adaptif matematis mahasiswa. Dengan demikian instrumen evaluasi berupa soal tes dapat digunakan untuk mengukur kemampuan penalaran adaptif matematis mahasiswa khususnya materi Limit.
\end{abstract}

Kata kunci: instrumen evaluasi; kemampuan penalaran adaptif; limit; pengembangan instrumen tes

\begin{abstract}
Improving first-year university students' mathematical adaptive reasoning skills is an undeniable challenge, particularly in subjects with a high level of abstraction. A compatible evaluation instrument needs to be developed to optimize students' adaptive mathematical reasoning skills. However, the evaluation instrument claimed appropriate for use is not available, particularly in Universitas Serang Raya. The feasibility of the evaluation instrument measured by the compliance of validity and reliability criteria during the development process. Hence, the purpose of this study is to develop an instrument for evaluating students' mathematical adaptive reasoning skills. Descriptive analysis used as the research approach, specifically in content analysis and expert review on the validity of the instrument through the instructional phases design stages, namely analysis and design, development and evaluation. In general, the test results of the validators' readability show the value of Asymp. Sig. > 0.05 means that the validators stated an equivalent consideration to the validity of the mathematical adaptive reasoning skills instrument. Thus the evaluation instrument in the form of test questions can be used to measure students' mathematical adaptive reasoning specifically in the Limit.
\end{abstract}

Keywords: Adaptive reasoning skills; evaluation instruments; instrument development; limit.

This is an open access article under the Creative Commons Attribution 4.0 International License

\section{PENDAHULUAN}

Kemampuan penalaran adaptif merupakan salah satu kemampuan yang diperlukan dalam prosedur memecah- kan masalah (Ludin, 2018; Jaroslawska et al., 2020). Hal tersebut yang menjadikan kemampuan penalaran adaptif masih menjadi prioritas untuk 
diteliti. Sebab lainnya karena penalaran sebagai pendukung peserta didik dalam menentukan dan melegitimasi strategi dalam proses pemecahan masalah (Spruijt et al., 2020). Sementara telah diketahui bersama bahwa pemecahan masalah dipandang sebagai salah satu tujuan kognitif dari suatu sistem pendidikan (Ristekdikti, 2015; OECD, 2018; Cha et al., 2020). Dengan demikian menelusuri kemampuan penalaran adaptif pada diri peserta didik masih menjadi fokus penting untuk dieksplorasi.

Kemampuan penalaran adaptif pada mahasiswa tingkat pertama universitas rata-rata sangat rendah (Kalinowski \& Willoughby, 2019; Richards et al., 2020) terutama dalam mata kuliah yang memiliki abstraksi tingkat tinggi seperti Kalkulus dan penerapannya (Ozgur et al., 2019; Chen \& Wu, 2020). Satu konsep materi dalam Kalkulus yang masih menjadi tantangan bagi mahasiswa tingkat pertama, khususnya mahasiswa di Prodi Pendidikan Matematika Universitas Serang Raya adalah Limit. Dalam penelusuran pendahuluan terkait materi Limit di Prodi Pendidikan Matematika Universitas Serang Raya dalam kurun waktu dua tahun diperoleh hasil pembelajaran yang menunjukkan bahwa rata-rata kesulitan yang dialami mahasiswa yaitu dalam menyusun dan menguji ada atau tidaknya nilai limit suatu fungsi. Kondisi demikian menjadikan mahasiswa terhambat dalam memperkirakan jawaban dari proses menyusun dan menguji ada atau tidaknya nilai limit suatu fungsi. Kesulitan tersebut dideteksi masuk pada kategori kemampuan penalaran untuk indikator menyusun dan menguji konjektur serta menganalisis situasi matematika dengan menggunakan pola (Oktaviyanthi, 2019). Fakta ini memberi indikasi bahwa kemampuan penalaran adaptif ini masih memunculkan masalah pada diri mahasiswa khususnya pada materi Limit. Jika situasi yang terjadi itu tidak ditanggulangi cepat, dimungkinkan tujuan kognitif dari pembelajaran Kalkulus terhambat untuk dicapai.

Bates \& Clark (2019) menyatakan salah satu faktor yang memungkinkan menjadi penyebab belum tergalinya kemampuan penalaran adaptif peserta didik adalah ketersediaan alat ukur yang kompatibel dan sesuai dengan tujuan capaian pembelajaran. Ditegaskan oleh Shin \& Lee (2019) bahwa keberhasilan proses pembelajaran secara utuh dan menyeluruh perlu didukung oleh perangkat pembelajaran, termasuk di dalamnya alat evaluasi, sebagai petunjuk teknis sehingga pelaksanaan pembelajaran dapat berjalan sesuai dengan tujuan yang ditetapkan. Shaughnessy et al. (2009) menyampaikan bahwa alat evaluasi ideal kemampuan penalaran adaptif adalah yang mampu memberi gambaran peserta didik dalam (1) membuat dan menginvestigasi konjektur matematika (make and investigate mathematical conjectures, (2) mengembangkan dan mengevaluasi argumentasi matematika (develop and evaluate mathematical arguments), (3) memilih dan menggunakan beragam tipe penalaran (select and use various types of reasoning). Selanjutnya poin-poin penilaian kemampuan penalaran adaptif matematis tersebut dikembangkan berdasarkan kebutuhan penelitian yakni untuk konsep Limit (Oktaviyanthi, 2019).

Kebutuhan alat $\begin{array}{r}\text { evaluasi } \\ \text { kemampuan penalaran }\end{array}$
matematis terutama dalam
bentuk tes
uraian masih menjadi prioritas


penelitian dalam lima tahun terakhir. Suprihatin et al. (2018) dan Indriani et al. (2017) mengembangkan tes kemampuan penalaran adaptif matematis pada jenjang SMP dengan masing-masing fokus materi yaitu Segitiga dan Geometri (Pythagoras). Sementara Yusdiana \& Hidayat (2018) dan Permana et al. (2020) mengembangkan tes kemampuan penalaran adaptif matematis untuk level SMA dan sederajat dengan materi Limit Fungsi dan HOT (Higher Order Thinking). Secara umum tes kemampuan penalaran adaptif matematis yang dikembangkan tersebut dinyatakan valid dan dapat digunakan serta memperoleh feedback yang baik ketika diimplementasikan. Berbeda dengan yang dilakukan Arifudin et al. (2016) dan Yenni \& Kurniasi (2018), tes kemampuan penalaran adaptif matematis yang dirancang dikolaborasikan dengan suatu model pembelajaran tertentu yakni Discovery Learning dan Inquiry Based Learning. Hasil pengembangan dan uji terbatas instrumen tes penelitian keduanya tersebut mengklaim adanya peningkatan kemampuan penalaran adaptif matematis siswa, khususnya pada materi Trigonometri dan Teori Bilangan. Namun belum terelaborasi evaluasi kemampuan penalaran adaptif berupa tes uraian dengan spesifikasi materi Limit khususnya pada jenjang universitas. Padahal masalah dalam penelitian ini, sebagaimana yang dijelaskan sebelumnya, difokuskan pada kelemahan mahasiswa dalam menyusun dan menguji ada atau tidaknya nilai limit suatu fungsi yang masuk kategori kemampuan penalaran adaptif matematis untuk indikator menyusun dan menguji konjektur serta menganalisis situasi matematika dengan menggunakan pola.
Selama kurun waktu dua tahun, evaluasi kemampuan penalaran adaptif matematis mahasiswa di Prodi Pendidikan Matematika Universitas Serang Raya tidak pernah dilakukan secara khusus, melainkan terintegrasi pada tes pemecahan masalah. Tes pemecahan masalah yang digunakan pun tidak disusun secara khusus, hanya menekankan pada level susah, menengah dan mudah. Namun kondisi demikian hanya memberikan informasi mengenai nilai mahasiswa secara angka, tetapi tidak merinci terhadap kemampuan penalaran adaptif matematis yang sudah dikuasai mahasiswa.

Dengan mempertimbangkan masalah yang dialami oleh mahasiswa, instrumen tes penalaran adaptif matematis disusun ditujukan untuk mengevaluasi kemampuan penalaran adaptif mahasiswa yang selanjutnya digunakan sebagai dasar untuk meningkatkan kemampuan penalaran adaptif mahasiswa. Oleh karena itu, untuk upaya memenuhi kebutuhan alat ukur tersebut, penelitian ini memokuskan pada proses menyusun dan merancang instrumen evaluasi kemampuan penalaran adaptif mahasiswa khususnya materi Limit serta melakukan serangkaian uji untuk memperoleh kelayakan penggunaan instrumen tersebut.

\section{METODE PENELITIAN}

Jenis penelitian yang digunakan adalah penelitian pengembangan dengan metode content analysis dan expert review (Richey et al., 2010). Penelitian ini didesain memokuskan pada validitas instrumen yang dikembangkan melalui tahapan instructional phases design yakni analysis and design, development dan evaluation. 
DOI: https://doi.org/10.24127/ajpm.v9i4.3150

Tahap pertama yaitu analysis and design (analisis dan desain) yang bertujuan menentukan masalah utama dan menetapkan desain solusi. Serangkaian kegiatan dilakukan di tahap ini seperti investigasi masalah melalui penelusuran proses pembelajaran sebelumnya, refleksi pengajar, respon mahasiswa, kondisi mahasiswa, solusi yang diambil, metode yang digunakan dan desain yang ditetapkan. Selanjutnya tahap kedua yakni development (pengembangan) yang ditujukan sebagai perwujudan ide dan konsep pada tahap analisis dan desain ke dalam bentuk visual yang visible. $\mathrm{Di}$ tahap pengembangan dilakukan perancangan instrumen sehingga menghasilkan prototipe instrumen sesuai standar penelitian yang disusun. Tahap terakhir yakni evaluation (evaluasi) yang menekankan pada ketercapaian indikator instrumen dan kelayakan penggunaan instrumen dalam skala luas. Adapun kegiatan evaluasi meliputi expert review melalui uji keseragaman dan uji keterbacaan, serta uji coba terbatas pada komunitas.

Penelitian dilakukan di Universitas Serang Raya dengan sampel mahasiswa pada program studi pendidikan matematika tingkat pertama yang mengambil mata kuliah Kalkulus sebanyak 60 orang. Pihak yang dilibatkan dalam penelitian pengembangan pembelajaran ini adalah 5 orang validator sebagai reviewer ahli yang terdiri dari 2 ahli di bidang matematika untuk menilai konten matematika, 2 ahli di bidang pendidikan matematika untuk menilai konten pengajaran dan pembelajaran, dan 1 ahli di bidang bahasa untuk menilai konten kebahasaan. Instrumen evaluasi berbentuk soal tes kemampuan penalaran adaptif dilakukan uji keseragaman validator menggunakan perhitungan
Statistika yakni uji Q-Cochran. Selanjutnya dilakukan ujicoba terbatas pada mahasiswa yang setara dengan subjek penelitian sebenarnya.

Terdapat tiga data dalam penelitian ini yaitu (1) data proses pengembangan produk yakni soal tes kemampuan penalaran adaptif matematis pada tahap analisis dan desain serta tahap pengembangan, (2) data kelayakan produk yang dihasilkan yaitu pada tahap evaluasi berupa expert review, dan (3) data hasil uji terbatas pada komunitas. Adapun teknik analisis data yang dilakukan terdiri atas reduksi data, penyajian data dan penyimpulan (Mihas, 2019).

\section{HASIL DAN PEMBAHASAN}

Tahap analisis dan desain

Analisis dilakukan melalui penelusuran proses pembelajaran sebelumnya yang dikuatkan dengan refleksi pengajar dan respon mahasiswa untuk menegaskan masalah utama yang dihadapi mahasiswa terkait penalaran adaptif matematis. Pembelajaran yang dilakukan pengajar menggunakan pembelajaran konvensional dimulai dengan pemaparan materi, contoh soal, tanya jawab, latihan, penekanan konsep. Refleksi pengajar yakni materi yang tersampaikan tidak dapat ditangkap detil oleh mahasiswa terlebih materi yang membahas soal konsep, contohnya konsep limit secara umum dan mengevaluasi limit menggunakan definisi formal. Hal tersebut terlihat dari nilai rata-rata capaian mahasiswa pada bab limit yang baru mencapai $48 \%$ dari nilai rata-rata minimal capaian standar yaitu $85 \%$ untuk 3 kriteria pemecahan masalah yakni representasi, rasionalisasi/penalaran dan pengambilan keputusan. Sementara respon mahasiswa yaitu penjelasan pengajar tentang konsep limit cukup dipahami, 
DOI: https://doi.org/10.24127/ajpm.v9i4.3150

namun tidak dapat dibayangkan detil terutama mengevaluasi nilai limit dengan definisi. Materi yang disampaikan cepat dicerna oleh pikiran dan cepat lenyap pula seiring waktu belajar di kelas selesai (Oktaviyanthi et al., 2016). Berdasarkan hal tersebut, dapat dinyatakan bahwa kemampuan penalaran adaptif matematis mahasiswa belum optimal (Oktaviyanthi, 2019).

Untuk mengoptimalkan kemampuan penalaran adaptif matematis mahasiswa maka perlu disusun instrumen evaluasi yang valid dan reliabel terkait materi limit. Instrumen evaluasi tersebut berupa tes berbentuk uraian dengan tujuan untuk melihat setiap langkah prosedur penyelesaian masalah yang melibatkan kemampuan penalaran adaptif yang dilakukan mahasiswa. Aspek yang dilihat pada soal tes mengacu pada indikator kemampuan penalaran adaptif terdiri dari 8 butir soal.

Penyusunan tes diawali dengan pembuatan kisi-kisi soal yang mencakup sub pokok bahasan, kemampuan yang diukur, indikator, dan jumlah butir soal (Tabel 1.). Selanjutnya membuat soal dan kunci jawaban berikut aturan pemberian skor untuk masing-masing butir soal. Prosedur lanjutan sebelum soal digunakan yaitu validasi oleh ahli di bidang matematika dan pendidikan matematika.

Tabel 1. Kisi-kisi soal tes penalaran adaptif.

\begin{tabular}{cclc}
\hline $\begin{array}{c}\text { Kemampuan } \\
\text { yang Diukur }\end{array}$ & \multicolumn{1}{c}{ Indikator } & $\begin{array}{c}\text { Nomor } \\
\text { Soal }\end{array}$ \\
\hline & A1.1 & $\begin{array}{l}\text { Memberikan penjelasan mengenai hubungan } x \text { yang mendekati } \\
\text { suatu bilangan tertentu dengan nilai } f(x) \text {-nya }\end{array}$ & $1 \mathrm{a}$ \\
\cline { 2 - 4 } & A1.2 & $\begin{array}{l}\text { Menarik kesimpulan logik dari hubungan perhitungan limit } \\
\text { secara numerik dengan nilai } f(x)\end{array}$ & $1 \mathrm{~b}$ \\
\cline { 2 - 4 } $\begin{array}{c}\text { Penalaran } \\
\text { Adaptif }\end{array}$ & A2.1 & $\begin{array}{l}\text { Memberikan alasan terhadap solusi dalam mencari nilai limit } \\
\text { suatu fungsi }\end{array}$ & 2 \\
\cline { 2 - 4 } & A2.3 & $\begin{array}{l}\text { Menarik generalisasi bahwa nilai limit L dari suatu fungsi } f(x) \\
\text { di titik } c \text { tidak bergantung pada nilai } f(c)\end{array}$ & 3 \\
\cline { 2 - 4 } & Aenyusun dan menguji ada atau tidaknya nilai limit suatu & $4 \mathrm{a}$ \\
\hline & A2.2 & $\begin{array}{l}\text { Memperkirakan jawaban dari proses menyusun dan menguji } \\
\text { ada atau tidaknya nilai limit suatu fungsi }\end{array}$ & $4 \mathrm{~b}$ \\
\hline & A3.2 & $\begin{array}{l}\text { Menganalisis nilai limit suatu fungsi konstan dengan } \\
\text { menggunakan pola }\end{array}$ & 5 \\
\cline { 2 - 4 } & A3.1 & $\begin{array}{l}\text { Menyusun pembuktian nilai limit suatu fungsi dengan definisi } \\
\text { formal limit }\end{array}$ & 6 \\
\hline
\end{tabular}

Dipilih 5 validator yang bertugas untuk memberikan pertimbangan, koreksi dan masukan didasarkan pada acuan validasi yang telah disusun peneliti. Adapun validasi yang dilakukan meliputi validasi muka yang didasarkan pada kejelasan butir soal baik dari aspek redaksi bahasa maupun ketepatan penggunaan simbol matematika untuk menghindarkan soal dari banyak tafsiran, dan validasi isi yang didasarkan pada kesesuaian butir soal dengan materi pokok penelitian yaitu Fungsi dan Limit dan indikatorindikator penelitian yang diukur.

Pemberian skor soal tes kemampuan penalaran adaptif secara kuantitatif disusun peneliti didasarkan 
DOI: https://doi.org/10.24127/ajpm.v9i4.3150

pada indikator kedua kemampuan tersebut. Masing-masing indikator memiliki skor yang bergantung pada deskripsi hasil jawaban soal subjek penelitian. Skor minimum dari setiap indikator adalah 0 dengan deskripsi hasil jawaban subjek penelitian yang tidak menunjukkan pemahaman terhadap soal dan tidak memberikan penjelasan. Sementara skor maksimum diberikan pada setiap indikator dengan deskripsi hasil jawaban subjek penelitian yang menunjukkan penyelesaian secara menyeluruh dan sesuai kunci jawaban. Nilai skor maksimum yang dapat diraih peserta didik adalah 25 .

\section{Tahap pengembangan}

Soal tes dirancang untuk mengukur kemampuan penalaran mahasiswa pada materi Limit. Oleh karenanya isi soal disusun bersesuaian dengan indikator kemampuan yang diteliti (Gambar. 1).

\begin{tabular}{|c|c|c|c|c|c|}
\hline $\begin{array}{c}\text { Kemampuan } \\
\text { matematis } \\
\text { yang diukur } \\
\end{array}$ & & Indikator & & No soal & Jawaban soal \\
\hline \multirow[t]{2}{*}{$\begin{array}{l}\text { Penalaran } \\
\text { Adaptif }\end{array}$} & A1.3 & $\begin{array}{l}\text { Menyusun dan } \\
\text { menguji a da atau } \\
\text { tidaknya nilai limit } \\
\text { suatu fungsi }\end{array}$ & 4 & $\begin{array}{l}\text { Diketahui } f(x)=\left\{\begin{array}{c}-1, x<0 \\
1, x>0\end{array}\right. \\
\text { a. Apakahnilai limit fungsi tersebut ada? } \\
\text { Bagaimana Anda mernunukkanada atau } \\
\text { tidaknyanilai limit fungsi tersebut? }\end{array}$ & $\begin{array}{l}\text { Dar } \\
\text { Darafik dapat diketahui bahwa } \\
\text { ketika } x \text { mendekati } 0 \text { dan negative, } \\
\text { maka nilai } f \text { sama dengan }-1 \text {. } \\
\text { Sedangkan ketika } x \text { mendekati } 0 \text { dan } \\
\text { positif, maka nilai } f \text { sama dengan } 1 \text {. }\end{array}$ \\
\hline & A 2.2 & $\begin{array}{l}\text { Memperkirakan } \\
\text { jawaban dariproses } \\
\text { menyusun dan } \\
\text { menguji ada atau } \\
\text { tidaknya nilailimit } \\
\text { suatu fungsi }\end{array}$ & & $\begin{array}{l}\text { b. Jelaskan alasan yang mendasari jawaban } \\
\text { Anda! }\end{array}$ & $\begin{array}{l}\text { Karena untuk } x \text { mendekati } 0 \text { dihasilkan } \\
\text { dari dua nilai } f \text { yang berbeda, maka } \\
\text { nilai } \lim _{x \rightarrow 0} f(x) \text { tidak ada. }\end{array}$ \\
\hline
\end{tabular}

Gambar 1. Tampilan kisi-kisi soal tes.
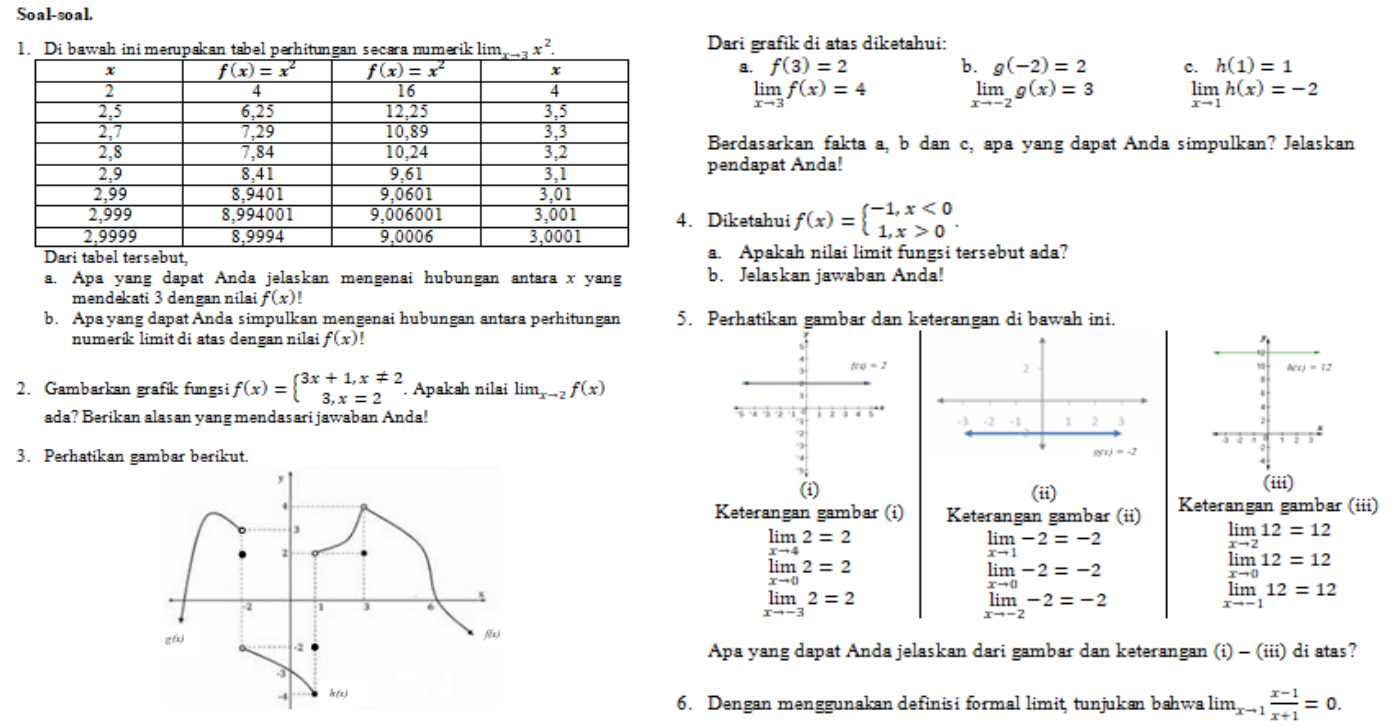

Gambar 2. Tampilan soal tes. 
DOI: https://doi.org/10.24127/ajpm.v9i4.3150

Bentuk instrumen evaluasi kemampuan penalaran adaptif adalah soal materi limit yang bersesuaian dengan indikator kemampuan yang diteliti (Gambar 2).

Data kemampuan penalaran adaptif dapat ditelusuri dari ketercapaian indikator kemampuan. Soal yang telah disesuaikan dengan indikator kemampuan diterjemahkan untuk menilai ketercapaian dalam bentuk skor. Tabel 2. memperlihatkan rincian pemberian skor soal per indikator kemampuan.

Tabel 2. Pedoman pemberian skor soal tes kemampuan penalaran adaptif.

\begin{tabular}{|c|c|c|c|c|}
\hline $\begin{array}{l}\text { Kemampuan } \\
\text { vang Diukur }\end{array}$ & & Indikator & Deskripsi & Skor \\
\hline & & Memberikan penjelasan & $\begin{array}{l}\text { Tidak memahami soal dan tidak } \\
\text { memberikan penjelasan }\end{array}$ & 0 \\
\hline & A1.1 & $\begin{array}{l}\text { mengenal hubungan } x \\
\text { yang mendekati suatu }\end{array}$ & $\begin{array}{l}\text { Memahami soal tetapi tidak } \\
\text { memberikan penjelasan }\end{array}$ & 1 \\
\hline & & $\begin{array}{l}\text { bilangan tertentu dengan } \\
\text { nilai } f(x) \text {-nya }\end{array}$ & $\begin{array}{l}\text { Memahami soal dan memberikan } \\
\text { penjelasan }\end{array}$ & 2 \\
\hline & & $\begin{array}{l}\text { Menarik kesimpulan } \\
\text { logik dari hubungan }\end{array}$ & $\begin{array}{l}\text { Tidak dapat menarik kesimpulan } \\
\text { logik }\end{array}$ & 0 \\
\hline & A1.2 & $\begin{array}{l}\text { perhitungan limit secara } \\
\text { numerik dengan nilai } \\
f(x)\end{array}$ & Dapat menarik kesimpulan logik & 1 \\
\hline & & & Tidak mampu menyelesaikan soal & 0 \\
\hline & & & $\begin{array}{l}\text { Menyelesaikan sebagian soal tetapi } \\
\text { menjawab salah }\end{array}$ & 1 \\
\hline & A2.1 & $\begin{array}{l}\text { Memberikan alasan } \\
\text { terhadap solusi dalam }\end{array}$ & $\begin{array}{l}\text { Menyelesaikan seluruh soal tetapi } \\
\text { menjawab salah }\end{array}$ & 2 \\
\hline & & fungsi & $\begin{array}{l}\text { Menyelesaikan sebagian soal dan } \\
\text { menjawab benar }\end{array}$ & 3 \\
\hline Penalaran & & & $\begin{array}{l}\text { Menyelesaikan seluruh soal dan } \\
\text { menjawab benar }\end{array}$ & 4 \\
\hline & & Menarik generalisasi & $\begin{array}{l}\text { Tidak memahami soal dan tidak } \\
\text { memberikan generalisasi }\end{array}$ & 0 \\
\hline & A2.3 & suatu fungsi $f(x)$ di titik & $\begin{array}{l}\text { Memahami soal dan tidak } \\
\text { memberikan generalisasi }\end{array}$ & 1 \\
\hline & & $\begin{array}{l}c \text { tidak bergantung pada } \\
\text { nilai } f(c)\end{array}$ & $\begin{array}{l}\text { Memahami soal dan memberikan } \\
\text { generalisasi }\end{array}$ & 2 \\
\hline & & & Tidak mampu menyelesaikan soal & 0 \\
\hline & & & $\begin{array}{l}\text { Menyelesaikan sebagian soal tetapi } \\
\text { menjawab salah }\end{array}$ & 1 \\
\hline & A1.3 & $\begin{array}{l}\text { Menyusun dan menguji } \\
\text { ada atau tidaknya nilai }\end{array}$ & $\begin{array}{l}\text { Menyelesaikan seluruh soal tetapi } \\
\text { menjawab salah }\end{array}$ & 2 \\
\hline & & limit suatu fungsi & $\begin{array}{l}\text { Menyelesaikan sebagian soal dan } \\
\text { menjawab benar }\end{array}$ & 3 \\
\hline & & & $\begin{array}{l}\text { Menyelesaikan seluruh soal dan } \\
\text { menjawab benar }\end{array}$ & 4 \\
\hline & & Memperkirakan jawaban & Tidak dapat memperkirakan jawaban & 0 \\
\hline & A 2.2 & $\begin{array}{l}\text { dan menguji ada atau } \\
\text { tidaknya nilai limit suatu }\end{array}$ & Dapat memperkirakan jawaban & 1 \\
\hline
\end{tabular}


DOI: https://doi.org/10.24127/ajpm.v9i4.3150

\begin{tabular}{|c|c|c|c|c|}
\hline \multirow{2}{*}{\multicolumn{2}{|c|}{$\begin{array}{l}\text { Kemampuan } \\
\text { yang Diukur }\end{array}$}} & Indikator & \multirow[t]{2}{*}{ Deskripsi } & \multirow[t]{2}{*}{ Skor } \\
\hline & & fungsi & & \\
\hline & \multirow{2}{*}{ A 3.2} & \multirow{2}{*}{$\begin{array}{l}\text { Menganalisis nilai limit } \\
\text { suatu fungsi konstan } \\
\text { dengan menggunakan } \\
\text { pola }\end{array}$} & $\begin{array}{l}\text { Tidak dapat menganalisis fungsi } \\
\text { konstan dengan pola }\end{array}$ & 0 \\
\hline & & & $\begin{array}{l}\text { Dapat menganalisis fungsi konstan } \\
\text { dengan pola }\end{array}$ & 1 \\
\hline & \multirow{5}{*}{ A 3.1} & \multirow{5}{*}{$\begin{array}{l}\text { Menyusun pembuktian } \\
\text { nilai limit suatu fungsi } \\
\text { dengan definisi formal } \\
\text { limit }\end{array}$} & $\begin{array}{l}\text { Tidak mampu menyusun pembuktian } \\
\text { nilai limit }\end{array}$ & 0 \\
\hline & & & $\begin{array}{l}\text { Menyelesaikan sebagian pembuktian } \\
\text { tetapi menjawab salah }\end{array}$ & 1 \\
\hline & & & $\begin{array}{l}\text { Menyelesaikan seluruh pembuktian } \\
\text { tetapi menjawab salah }\end{array}$ & 2 \\
\hline & & & $\begin{array}{l}\text { Menyelesaikan sebagian pembuktian } \\
\text { dan menjawab benar }\end{array}$ & 3 \\
\hline & & & $\begin{array}{l}\text { Menyelesaikan seluruh pembuktian } \\
\text { dan menjawab benar }\end{array}$ & 4 \\
\hline
\end{tabular}

\section{Tahap evaluasi}

Tahap evaluasi soal tes kemampuan penalaran adaptif dilakukan dengan uji expert review melalui uji keseragaman dan uji keterbacaan serta ujicoba terbatas. Uji keseragaman dan keterbacaan dilakukan dengan cara yang sama dengan instrumen perangkat pembelajaran dan bahan ajar yakni menggunakan uji $Q$ Cochran. Hasil validasi muka dan isi dari soal tes kemampuan penalaran pada Tabel 3.

Tabel 3. Uji keseragaman dan keterbacaan soal tes.

\begin{tabular}{ccc}
\hline \multirow{2}{*}{ Instrumen } & \multicolumn{2}{c}{ Uji Q-Cochran (Asymp. Sig.) } \\
\cline { 2 - 3 } & Validitas Muka & Validitas Isi \\
\hline Soal tes kemampuan penalaran & 0,323 & 0,406 \\
\hline
\end{tabular}

Tabel 4. Rekapitulasi hasil ujicoba terbatas soal tes.

\begin{tabular}{lrllcccc}
\hline $\begin{array}{c}\text { No } \\
\text { Soal }\end{array}$ & $\mathbf{t}_{\text {hitung }}$ & $\mathbf{t}_{\text {tabel }}$ & Validitas & $\sum \sigma_{i}^{2}$ & $\boldsymbol{r}$ & $\begin{array}{c}\text { Tingkat } \\
\text { Kesukaran }\end{array}$ & Kategori \\
\hline $1 \mathrm{a}$ & 5,57 & 1,671 & Valid & 0,98 & & 0,43 & Sedang \\
$1 \mathrm{~b}$ & 3,66 & 1,671 & Valid & 1,25 & & 0,64 & Sedang \\
2 & 3,57 & 1,671 & Valid & 2,88 & & 0,89 & Mudah \\
3 & 5,20 & 1,671 & Valid & 1,45 & 0,89 & 0,52 & Sedang \\
$4 \mathrm{a}$ & 11,11 & 1,671 & Valid & 5,51 & & 0,78 & Mudah \\
$4 \mathrm{~b}$ & 11,11 & 1,671 & Valid & 0,98 & & 0,83 & Mudah \\
5 & 5,03 & 1,671 & Valid & 4 & & 0,35 & Sedang \\
6 & 8,45 & 1,671 & Valid & 4,49 & & 0,91 & Mudah \\
\hline
\end{tabular}

Hasil validasi muka dan isi di Tabel 3. menunjukkan nilai Asymp. Sig. $>0,05$ yang memberi pengertian bahwa kelima validator memberi pertimbangan seragam pada validitas muka dan isi soal tes kemampuan penalaran. Nilai tersebut memberikan indikasi bahwa soal tes yang disusun dapat digunakan untuk mengukur kemampuan penalaran adaptif matematis mahasiswa tingkat pertama pada materi Limit. Selanjutnya dilakukan ujicoba terbatas pada 60 
orang mahasiswa untuk memperoleh validitas butir soal, reliabilitas soal sesuai standar yang disusun dan tingkat kesukaran soal. Tabel 4. menginformasikan nilai-nilai ujicoba instrumen soal tes tersebut.

Tabel 4. menjelaskan bahwa untuk $\mathrm{N}=60$ dengan taraf signifikansi $5 \%$, diperoleh $t_{\text {kritis }}$ yaitu 1,671. Jika nilai $t_{\text {hitung }}>t_{\text {kritis }}$ maka butir soal dikatakan valid. Dengan demikian berdasarkan rekapitulasi ujicoba terbatas dikatakan 8 butir soal tes kemampuan penalaran adaptif matematis mahasiswa layak digunakan. Sementara keajegan soal tes dihitung menggunakan Alpha-Cronbach dengan keputusan soal tes reliabel jika $r_{\text {hitung }}>$ $r_{\text {tabel. }}$ Dari perhitungan Tabel 4. diketahui 8 butir soal tes memiliki nilai $\mathrm{r}_{\text {hitung }}>\mathrm{r}_{\text {tabel }}$ sehingga soal tes dinyatakan reliabel. Selanjutnya untuk tingkat kesukaran soal tes melalui perbandingan jumlah skor yang diperoleh mahasiswa pada butir soal ke$i$ dengan jumlah skor ideal pada butir soal tersebut diperoleh masing-masing 4 butir soal tes pada kategori sedang dan mudah.

Penelitian ini menghasilkan
instrumen evaluasi kemampuan
penalaran adaptif matematis berbentuk
soal tes sesuai prosedur penelitian pengembangan. Proses dimulai dari tahap analisis dan desain dimana semua informasi awal terkait latar belakang dilakukannya penelitian pengembangan didalami dan ditelusuri dengan rinci. Hal tersebut dilakukan untuk memperoleh informasi yang utuh dan menyeluruh mengenai masalah utama penelitian dan kemungkinan penyelesaian yang dapat diambil. Sebagaimana disampaikan Sharif \& Cho (2015) bahwa jembatan antara gap masalah dengan alternatif penyelesaian masalah salah satunya bertumpu di kegiatan analisis awal. Temuan pada tahap analisis dan desain yaitu 8 butir soal tes yang mengacu pada indikator kemampuan penalaran adaptif matematis dikhususkan pada materi Limit (Tabel 1). Menetapkan indikator kemampuan penalaran adaptif matematis langsung pada materi yang dikembangkan menjadi salah satu upaya pembentukan dan pendalaman materi. Hal ini sebagaimana yang diulas oleh Lazonder \& Janssen (2019) dalam penelitiannya mengenai validasi instrumen butir tes kemampuan penalaran bahwa indikator kemampuan yang langsung dipadankan pada materi yang menjadi masalah bagi siswa dapat menstimulasi domain kognitif dimana proses bernalar bekerja. Selain itu, indikator yang disusun dalam penelitian ini dibuat lebih adaptif bersesuaian dengan materi yang dianggap sulit oleh mahasiswa sekaligus menjadi pembeda dan pelengkap penelitian sebelumnya mengenai analisis kemampuan penalaran adaptif pada materi Limit (Yusdiana \& Hidayat, 2018).

Tahap pengembangan dipandang sebagai bentuk manifestasi ide yang telah dielaborasi di tahap analisis dan desain. Capaian pada tahap ini adalah prototipe pembelajaran yang siap untuk dilakukan serangkaian uji sebagaimana yang disebutkan Beaudouin-Lafon \& Mackay (2009) bahwa tahap pengembangan sebagai prototyping stage. Pada tahap pengembangan dalam penelitian ini, desain yang telah dirancang di tahap sebelumnya diwujudkan menjadi instrumen yang utuh. Hal tersebut dipenuhi bukan hanya sebagai visualisasi ide namun untuk memudahkan validator melakukan penilaian di tahap evaluasi. Temuan penelitian di tahap pengembangan ini yaitu instrumen butir soal kemampuan penalaran adaptif matematis yang 
memenuhi standar minimal indikator ketercapaian melalui proses koreksi dan revisi dengan validator ahli. Susunan redaksi dari pertanyaan maupun pernyataan dalam 8 butir soal di penelitian pengembangan ini menjadi keutamaan karena telah disesuaikan dengan indikator yang ingin dicapai. Hasil tersebut sejalan dengan beberapa penelitian terkait soal tes kemampuan penalaran adaptif matematis diantaranya Arifudin et al. (2016), Indriani et al. (2017), dan Suprihatin et al. (2018).

Tabel 5. Revisi instrumen evaluasi kemampuan penalaran adaptif.

\begin{tabular}{|c|c|c|}
\hline $\begin{array}{c}\text { Nomor } \\
\text { Soal }\end{array}$ & Soal Sebelum Perbaikan & Revisi \\
\hline 4 & $\begin{array}{l}\text { Diketahui } f(x)= \\
\left\{\begin{array}{c}-1, x<0 \text { tidak memiliki nilai } \\
1, x>0\end{array}\right. \\
\text { limit. Apakah Anda setuju } \\
\text { dengan pernyataan tersebut? } \\
\text { Jelaskan pendapat Anda! }\end{array}$ & $\begin{array}{l}\text { Diketahui } f(x)=\left\{\begin{array}{c}-1, x<0 \\
1, x>0\end{array}\right. \\
\text { a. Apakah nilai limit fungsi tersebut } \\
\quad \text { ada? } \\
\text { b. Jelaskan jawaban Anda! }\end{array}$ \\
\hline 5 & $\begin{array}{l}\text { Dengan menggunakan grafik, } \\
\text { tunjukkan dan jelaskan bahwa: } \\
\begin{aligned} \text { a. } & \lim _{x \rightarrow c} k=k \\
\text { b. } & \lim _{x \rightarrow c} x=c\end{aligned}\end{array}$ & $\begin{array}{l}\text { Perhatikan gambar dan keterangan di } \\
\text { bawah ini. } \\
\text { Keterangan gambar (i) } \\
\qquad \lim _{x \rightarrow 4} 2=2 \\
\qquad \lim _{x \rightarrow 0} 2=2 \\
\qquad \lim _{x \rightarrow-3} 2=2 \\
\text { Keterangan gambar (ii) } \\
\qquad \lim _{x \rightarrow 1}-2=-2 \\
\qquad \lim _{x \rightarrow 0}-2=-2 \\
\qquad \lim _{x \rightarrow-2}-2=-2 \\
\text { Keterangan gambar (iii) } \\
\quad \lim _{x \rightarrow 2} 12=12 \\
\quad \lim _{x \rightarrow 0} 12=12 \\
\text { Apa yang dapat Anda jelaskan dari } \\
\text { gambar dan keterangan (i) - (iii) di } \\
\text { atas? }\end{array}$ \\
\hline
\end{tabular}

Tahap evaluasi dari suatu penelitian pengembangan merupakan tahap kritis siap tidaknya suatu produk penelitian diimplementasikan secara luas (Schott \& Seel, 2015). Adapun yang dilakukan dalam tahap evaluasi pada penelitian ini adalah uji expert melalui uji keseragaman dan uji keterbacaan, dan ujicoba terbatas.
Common \& Lane (2017) menyebutkan salah satu kondisi suatu perangkat penelitian dapat digunakan dalam skala luas yaitu hasil uji keseragaman para ahli. Hasil uji keseragaman validator ahli menilai bahwa butir soal tes yang disusun telah memenuhi standar minimal indikator dan dapat digunakan untuk mengambil data kemampuan 
penalaran adaptif matematis mahasiswa tingkat pertama pada materi Limit (Tabel 3). Hasil tersebut bersesuaian dengan hasil penelitian yang dilakukan oleh Yusdiana \& Hidayat (2018), dan Permana et al. (2020). Namun demikian, instrumen penelitian yang dinilai tersebut banyak mendapat masukan dari validator ahli dan mengalami proses koreksi, revisi, refleksi sampai diperoleh instrumen yang memenuhi standar minimal. Adapun contoh butir soal yang mengalami revisi disajikan pada Tabel 5.

Pada Tabel 5. butir soal nomor 4 digunakan untuk mengukur dua indikator, A1.3 dan A2.2. Validator memberi saran untuk mepertimbangkan memilih pertanyaan dimana mahasiswa dapat mencari sendiri jawaban dan mengonstruksi alasannya. Menurut validator, kalimat 'tidak memiliki limit' dimungkinkan dapat menghasilkan jawaban mahasiswa yang tidak berdasarkan pengetahuannya sehingga lebih baik dihilangkan. Validator menyampaikan masukan untuk menggantinya dengan 'apakah nilai limit fungsi tersebut ada?' sebagai stimulus mahasiswa memberikan alasan logis berdasarkan hasil yang diperolehnya sendiri. Selanjutnya untuk butir soal nomor 5, validator menyatakan bahwa butir soal nomor 5 kurang sesuai untuk mengukur pola dan hubungan sebagai situasi matematika yang harus dianalisis mahasiswa. Saran perbaikan yang disampaikan yakni tampilkan suatu pola dan hubungan yang dapat menggiring mahasiswa untuk menyimpulkan bahwa $\lim _{x \rightarrow c} k=k$ dan $\lim _{x \rightarrow c} x=c$ sebagaimana yang sesuai dengan indikator.

Kegiatan selanjutnya pada tahap evaluasi yakni ujicoba terbatas dilakukan untuk memperoleh validitas, reliabilitas tes sesuai standar yang disusun, melihat tingkat keterbacaan bahasa dan mendapatkan gambaran tentang setiap soal yang digunakan untuk mengukur kemampuan penalaran adaptif mahasiswa. Validitas empirik tes kemampuan penalaran adaptif ditinjau dari kriteria tertentu yang digunakan untuk menentukan tinggi rendahnya koefisien validitas alat evaluasi yang disusun (Common \& Lane, 2017).

Dari Tabel 4. dapat diinformasikan bahwa 8 butir soal yang dirancang memiliki kelayakan dan dinyatakan valid berdasarkan perhitungan Statistika untuk digunakan mengukur kemampuan penalaran adaptif dengan interpretasi soal sangat tinggi (ST) 3 soal, soal sedang (SD) 3 soal dan soal mudah (M) 2 soal. Untuk konsistensi dan ketetapan soal tes, hasil perhitungan menunjukkan bahwa soal tes dinyatakan reliabel dan berada pada kategori reliabilitas sangat tinggi. Mohajan (2017) menyatakan bahwa jika suatu alat ukur penelitian disimpulkan valid dan reliabel, maka alat ukur tersebut dikatakan layak untuk menjadi alat pengumpul data penelitian. Selanjutnya uji daya pembeda soal dilakukan untuk meyakinkan bahwa soal tes yang dirancang ini dapat membedakan mahasiswa yang belum atau sudah menguasai kompetensi kemampuan penalaran adaptif. Rata-rata soal tes kemampuan penalaran adaptif berada pada kriteria daya pembeda soal sedang, artinya instrumen tersebut cukup memenuhi kriteria standar soal untuk membedakan subjek penelitian yang menguasai kompetensi penalaran adaptif. DeMonbrun et al. (2017) mengulas kriteria soal yang representatif adalah yang bersifat universal artinya soal tersebut dapat mengukur suatu kemampuan dalam diri 
DOI: https://doi.org/10.24127/ajpm.v9i4.3150

siswa dari beragam karakter dan kategori.

Secara umum keunggulan alat evaluasi kemampuan penalaran adaptif matematis melalui bentuk soal tes dalam penelitian ini yaitu indikator kemampuan penalaran adaptif matematis yang ditetapkan dibuat lebih adaptif bersesuaian dengan materi yang dianggap sulit oleh mahasiswa sebagai upaya pembentukan dan pendalaman materi. Sementara yang menjadi kelemahannya adalah instrumen butir soal baru terfokus pada materi Limit. Dengan dihasilkannya soal tes yang mampu mengukur kemampuan penalaran adaptif matematis secara lebih representatif pada materi Limit, memberi penguatan pada mahasiswa dalam menyusun dan menguji ada atau tidaknya nilai limit suatu fungsi. Sehingga kelemahan mahasiswa dalam belajar Limit dapat diminimalisir (Yusdiana \& Hidayat, 2018; Yenni \& Kurniasi, 2018). Selain itu, potensi lain yang dapat dikembangkan sebagai dampak dari pengembangan soal tes ini yaitu berkembang pula peluang menyusun soal tes dengan fokus materi lain yang menjadi kesulitan mahasiswa melalui prosedur yang serupa (Turner, 2013).

\section{KESIMPULAN DAN SARAN}

Berdasarkan hasil dan pembahasan diperoleh instrumen evaluasi kemampuan penalaran adaptif matematis berbentuk soal tes berjumlah 8 butir. Hasil uji keseragaman dan keterbacaan oleh 5 validator menunjukkan bahwa kelima validator memberi pertimbangan seragam pada validitas muka dan isi instrumen evaluasi kemampuan penalaran adaptif yang ditunjukkan dari nilai Asymp. Sig. $>0,05$. Indikasinya adalah soal tes tersebut dapat digunakan untuk menjaring data kemampuan penalaran adaptif matematis mahasiswa tingkat pertama dengan fokus materi Limit. Selanjutnya berdasarkan hasil ujicoba terbatas pada 60 sampel mahasiswa diperoleh hasil bahwa 8 butir soal yang dirancang tersebut memiliki kelayakan dan dinyatakan valid untuk digunakan mengukur kemampuan penalaran adaptif. Adapun rekomendasi sebagai tindak lanjut penelitian yang berkelanjutan yakni melakukan eksperimen implementasi soal tes pada subjek yang lebih luas untuk memperoleh feedback yang lebih banyak sebagai bahan perbaikan instrumen. Selain itu, perlu dilakukan pula pengembangan soal tes jika dikolaborasikan dengan penerapan model atau pendekatan pembelajaran tertentu. Selanjutnya untuk mendukung pembelajaran era pandemik berbasis daring, dapat dirancang soal tes kemampuan penalaran adaptif matematis elektronik yang interaktif.

\section{DAFTAR PUSTAKA}

Arifudin, M., Wilujeng, H., \& Utomo, R. B. (2016). Pengaruh Metode Discovery Learning Pada Materi Trigonometri Terhadap Kemampuan Penalaran Adaptif Siswa SMA. Kalamatika: Jurnal Pendidikan Matematika,1(2), 129-140.

Bates, T. A., \& Clark, P. C. (2019) Reliability and validity of the simulation learning effectiveness inventory. Journal of Professional Nursing, 35(6), 461-466. doi: 10.1016/j.profnurs.2019.04.007.

Beaudouin-Lafon, M., \& Mackay, W. E. (2009). Prototyping tools and techniques. Human-Computer Interaction , 137-160.

Cha, H., Park, T., \& Seo, J. (2020). What Should Be Considered when 
DOI: https://doi.org/10.24127/ajpm.v9i4.3150

Developing ICT-Integrated
Classroom Models for a
Developing
Country?. Sustainability, 12(7),
2967.

Chen, C. L., \& Wu, C. C. (2020). Students' behavioral intention to use and achievements in ICTIntegrated mathematics remedial instruction: Case study of a calculus course. Computers \& Education, 145, 103740.

Common, E. A., \& Lane, K. L. (2017). Social validity assessment. Applied behavior analysis advanced guidebook, 73-92.

DeMonbrun, M., Finelli, C. J., Prince, M., Borrego, M., Shekhar, P., Henderson, C., \& Waters, C. (2017). Creating an instrument to measure student response to instructional practices. Journal of Engineering Education, 106(2), 273-298.

Indriani, T., Hartoyo, A., \& Astuti, D. (2017). Kemampuan penalaran adaptif siswa dalam memecahkan masalah kelas VIII SMP Pontianak. Jurnal Pendidikan dan Pembelajaran Khatulistiwa, 6(2), 1-12.

Jaroslawska, A. J., McCormack, T., Burns, P., \& Caruso, E. M. (2020). Outcomes versus intentions in fairness-related decision making: School-aged children's decisions are just like those of adults. Journal of experimental child psychology, 189, 104704.

Kalinowski, S. T., \& Willoughby, S. (2019). Development and validation of a scientific (formal) reasoning test for college students. Journal of Research in Science Teaching, 56(9), 12691284.
Lazonder, A. W., \& Janssen, N. (2019). Development and initial validation of a performance-based scientific reasoning test for children. Studies in Educational Evaluation, 68, 100951.

Ludin, S. M. (2018). Does good critical thinking equal effective decisionmaking among critical care nurses? A cross-sectional survey. Intensive and Critical Care Nursing, 44, 1-10.

Mihas, P. (2019). Qualitative data analysis. Oxford Research Encyclopedia of Education.

Mohajan, H. K. (2017). Two criteria for good measurements in research: Validity and reliability. Annals of Spiru Haret University. Economic Series, 17(4), 59-82.

OECD. (2018). The Future of Education and Skills: Education 2030. Paris: OECD.

Oktaviyanthi, R., Supriani, Y., \& Agus, R. N. (2016). A Preliminary Study: Students' Initial Mathematical Skills Review in Adaptive Reasoning and Decision Making. (Laporan Penelitian, Universitas Serang Raya).

Oktaviyanthi, R. (2019). Meningkatkan Kemampuan Penalaran Adaptif, Pengambilan Keputusan dan Selfdirected Learning Mahasiswa Pendidikan Matematika Melalui Pembelajaran Cognitive Apprenticeship Berbantuan Selfpaced Video (Disertasi Doktor, Universitas Pendidikan Indonesia).

Ozgur, Z., Ellis, A. B., Vinsonhaler, R., Dogan, M. F., \& Knuth, E. (2019). From examples to proof: Purposes, strategies, and affordances of example use. The Journal of Mathematical Behavior, 53, 284-303. 
DOI: https://doi.org/10.24127/ajpm.v9i4.3150

Permana, N. N., Setiani, A., \& Nurcahyono, N. A. (2020). Analisis Kemampuan Penalaran Adaptif Siswa dalam Menyelesaikan Soal Higher Order Thinking Skills (HOTS). Jurnal Pengembangan Pembelajaran Matematika, 2(2), 51-60.

Richards, J. B., Hayes, M. M., \& Schwartzstein, R. M. (2020). Teaching Clinical Reasoning and Critical Thinking: From Cognitive Theory to Practical Application. Chest, 158(4), 16171628.

Richey, R. C., Klein, J. D., \& Tracey, M. W. (2010). The instructional design knowledge base: Theory, research, and practice. New York: Routledge.

Ristekdikti. (2015). Peraturan menteri riset, teknologi, dan pendidikan tinggi Republik Indonesia nomor 44 tahun 2015 tentang Standar Nasional Pendidikan Tinggi. Jakarta: Kemenristekdikti.

Schott, F., \& Seel, N. M. (2015). Instructional Design. International Encyclopedia of the Social \& Behavioral Sciences, 196-200. doi:10.1016/b978-0-08097086-8.92032-4

Sharif, A., \& Cho, S. (2015). 21 stCentury Instructional Designers: Bridging the Perceptual Gaps between Identity, Practice, Impact and Professional Development. International Journal of Educational Technology in Higher Education, 12(3), 72-85.

Shaughnessy, M., Chance, B. L., Kranendonk, H., \& National Council of Teachers of Mathematics. (2009). Focus in high school mathematics: Reasoning and sense making in statistics and probability. Reston: National Council of Teachers of Mathematics.

Shin, J., \& Lee, J. H. (2019). Multitimescale, multi-period decisionmaking model development by combining reinforcement learning and mathematical programming. Computers \& Chemical Engineering, 121, 556573.

Spruijt, A. M., Ziermans, T. B., Dekker, M. C., \& Swaab, H. (2020). Educating parents to enhance children's reasoning abilities: A focus on questioning style. Journal of Applied Developmental Psychology, 66, 101102.

Suprihatin, T. R., Maya, R., \& Senjayawati, E. (2018). Analisis Kemampuan Penalaran Matematis Siswa SMP pada Materi Segitiga dan Segiempat. Jurnal Kajian Pembelajaran Matematika,2(1), 9-13.

Turner, R. (2013). Adaptive reasoning for real-world problems: A schema-based approach. New York: Psychology Press. doi: 10.4324/9780203773185

Yenni, Y., \& Kurniasi, E. R. (2018). Pengembangan $1 \mathrm{~km}$ berbasis inquiry untuk mengoptimalkan kemampuan penalaran adaptif. Jurnal Analisa, 4(2), 6171.

Yusdiana, B. I., \& Hidayat, W. (2018). Analisis Kemampuan Penalaran Matematis Siswa SMA pada Materi Limit Fungsi. Jurnal Pembelajaran Matematika Inovatif, 1(3), 409-414. 